\title{
Weakened seasonality of the African rainforest precipitation in boreal winter and spring driven by tropical SST variabilities
}

Xin-Yue Wang ${ }^{1,2}$, Jiang Zhu ${ }^{1,2}$, Meijiao Xin ${ }^{1,2}$, Chentao Song ${ }^{1,2}$, Yadi Li $i^{1,2}, Y_{i} Z_{\text {hou }}{ }^{1,2}$ and Xichen Li $^{1,3^{*}}$ (D)

\begin{abstract}
Precipitation in the equatorial African rainforest plays an important role in both the regional hydrological cycle and the global climate variability. Previous studies mostly focus on the trends of drought in recent decades or long-time scales. Using two observational datasets, we reveal a remarkable weakening of the seasonal precipitation cycle over this region from 1979 to 2015, with precipitation significantly increased in the boreal winter dry season ( $0.13 \mathrm{~mm} /$ day/decade) and decreased in the boreal spring wet season ( $0.21 \mathrm{~mm} /$ day/decade), which account for $\sim 14 \%$ (the precipitation changes from 1979 to 2015) of their respective climatological means. We further use a state-of-theart atmospheric model to isolate the impact of sea surface temperature change from different ocean basins on the precipitation changes in the dry and wet seasons. Results show that the strengthening precipitation in the dry season is mainly driven by the Atlantic warming, whereas the weakening precipitation in the wet season can be primarily attributed to the Indian Ocean. Warming Atlantic intensifies the zonal circulation over the African rainforest, strengthening moisture convergence and intensifying precipitation in the boreal winter dry season. Warming Indian Ocean contributes more to reducing the zonal circulation and suppressing the convection in the boreal spring wet season, leading to an opposite effect on precipitation. This result has important implication on local ecology as well as global climate system.
\end{abstract}

Keywords: Seasonality of precipitation, African rainforest, Walker circulation, Convergence of moisture

\section{Introduction}

African rainforest, located in the Congo Basin, is the world's second-largest tropical forest region (Malhi et al. 2013; Mayaux et al. 2013; Fig. 1a). Rainforests play important roles in hydrology and carbon storage due to their rich biodiversity and high ecological function (Baccini et al. 2012; Saatchi et al. 2011). African rainforest is one of three key convective regions, and the other two are Maritime Continent and Amazon basin (Washington et al. 2013; Todd and Washington 2004). Deep convection and diabatic heating over three regions drive

\footnotetext{
*Correspondence: lixichen@mail.iap.ac.cn

${ }^{1}$ Institute of Atmospheric Physics, Chinese Academy of Sciences, Beijing, China

Full list of author information is available at the end of the article
}

the global tropical circulation (Hart et al. 2019; Webster 1973), which make great contributions to the global climate system. In addition, deep convection over the African rainforest is larger than any other region in the global tropics, dominating the global tropical rainfall distribution in the transition seasons (Washington et al. 2013). However, long-term drying trend occurred over the equatorial western and central Africa (Asefi-Najafabady and Saatchi 2013; Diem et al. 2014; Hua et al. 2016; Malhi and Wright 2004; Yin and Gruber 2010), resulting in a declining of Congo rainforest greenness and altering the forest structure (Chambers and Roberts 2014; Zhou et al. 2014). Therefore, it is crucial to understand the change of climate in African rainforest regions, in particular precipitation in different seasons. 


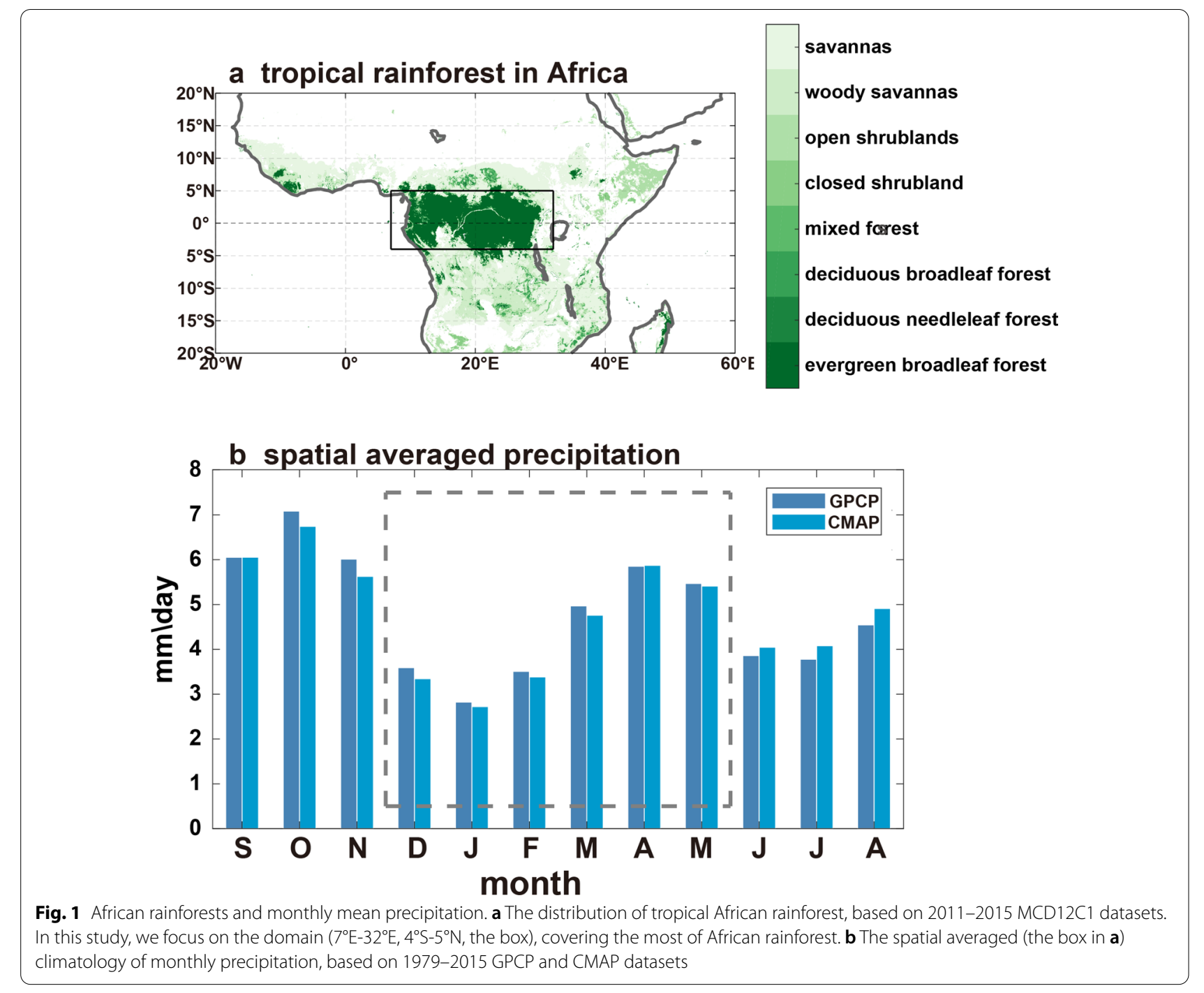

Rainfall in equatorial Africa is affected by the shift of the intertropical convergence zone (ITCZ, Nicholson 2018; Sultan and Janicot 2000) and is related to West African monsoon (Nicholson 2009; Redelsperger et al. 2006; Thorncroft et al. 2011) and local zonal circulation (Leduc-Leballeur et al. 2013; Nicholson and Dezfuli 2013; Williams and Funk 2011). An upward branch of Walker circulation over the Congo Basin and a downward branch over the Gulf of Guinea play important roles in the process of precipitation over the West Africa (Cook and Vizy 2016). Deep convection caused by ascending motion over the Congo Basin is positively associated with precipitation in West Africa (Cook and Vizy 2016) while subsidence makes a contribution to maintain moisture transport into this region (Dezfuli et al. 2015). Some regional factors, such as topography, mid-level jets, and mesoscale convective systems all influence precipitation
(Jackson et al. 2009; Nicholson 2009; Pokam et al. 2012). Under the impact of these complex factors, the seasonal cycle of equatorial African precipitation is characterized by a bimodal feature, with two rainy seasons (March, April, May, MAM; September, October, November, SON) and two dry seasons (June, July, August, JJA; December, January, February, DJF) (Creese and Washington 2018; Washington et al. 2013; Fig. 1b).

There is a seasonal difference in driving the variation of regional precipitation by sea surface temperature (SST) forcing (Balas et al. 2007; Farnsworth et al. 2011). On intraseasonal timescales, the equatorial SST cooling plays a role in the precipitation along the African coast during boreal spring (Leduc-Leballeur et al. 2013). On interannual timescales, Atlantic SST governs the movement of the ITCZ and further influence boreal summer precipitation in equatorial Africa (Nicholson 2009). The Indian 
Ocean is more related to rainfall in late summer/early fall, whereas Pacific is important for central Africa in MAM (Balas et al. 2007; DiNezio et al. 2013; Farnsworth et al. 2011). However, ENSO is less directly connected to African rainforest precipitation (Malhi and Wright 2004). Long-term drought in West and Central Africa is mainly linked to the change of Atlantic circulation (Shanahan et al. 2009) and SST (Camberlin et al. 2001; Diem et al. 2014), and warming Indian Ocean also makes an important contribution (Diem et al. 2014; Hoerling et al. 2006; Hua et al. 2016; Richard et al. 2001). In boreal winter/ spring season, tropical North Atlantic may force anomalous circulation and increased precipitation in central equatorial Africa (Todd and Washington 2004). Additionally, Pacific SST can also modulate precipitation over eastern and southern Africa by atmospheric bridge (Dezfuli et al. 2013; Hua et al. 2016; Maidment et al. 2015).

Previous studies indicated that long-term dry trend caused the shrinking of Congo rainforest (Zhou et al. 2014). It is also reported that the dry season (JJA) length has been increased by 6.4-10.4 days per decade in the period of 1988-2013 over the Congo rainforest (Jiang et al. 2019), which is mainly relates to an earlier dry season onset and a delayed dry season end. The decreased precipitation during AMJ (April, May, June) result in the decline of soil moisture and further cause the longer boreal summer (JJA) dry season over the Congo rainforest (Jiang et al. 2019). In East Africa, the precipitation in MAM (defined as "long rains") decreased due to abrupt change of tropical Pacific SST (Lyon and DeWitt 2012). In addition, anthropogenic forcing has influenced the decreasing trend in rainfall over the northern African monsoon to a great extent ( $\mathrm{Ha}$ et al. 2020). However, changes in extreme precipitation events in the dry season (JJA) of the Congo Basin do not come from an anthropogenic climate signal (Otto et al. 2013). Many efforts have been devoted to study the precipitation in dry and wet seasons under global warming and found models show large uncertainties (Creese and Washington 2018; James et al. 2013). Up to now, most of these studies concentrate on either one season or the projection of models in African rainforest precipitation. However, the change in seasonalities between dry and wet seasons in recent decades is not very well investigated because of extremely limited observation stations. Meanwhile, the mechanism causing the change of precipitation seasonality remains unclear.

In the rest of this paper, we focus on the recent decadal trend in dry season of boreal winter (DJF) and boreal spring wet season (AM) over the equatorial African rainforest region, by combining observed datasets and atmospheric model simulations. We describe the datasets, the statistical methods, and the model experiments in "Methods" section, and examine the observed recent long-term trends in the dry and wet seasons in "Results" section. We found that the seasonality of precipitation over the African rain forest is weakening over the past $\sim$ four decades, i.e., precipitation has significantly increased in the boreal winter dry season and decreased in the boreal spring wet season. Further, we investigate the impacts of tropical SSTs on the observed precipitation changes using atmospheric model simulations in "Results" section. The change of specific humidity, moisture flux and Walker circulation forced by SST over the African rainforest region are presented in "Results" section. Finally, conclusions and discussions are given in last section.

\section{Methods}

In this study, we use MODIS land cover map dataset (MCD12C1, Friedl et al. 2010) to describe the distribution of the African rainforest. To examine the precipitation change, we used two observed precipitation datasets, the Global Precipitation Climatology Project (GPCP, Huffman et al. 2009) and the CPC Merged Analysis of Precipitation (CMAP, Xie and Arkin 1997). These datasets are based on gauge stations and satellite observations, and are widely used as reliable precipitation measurements (Yin et al. 2004). The pattern of tropical SST in recent decades has an important impact on precipitation change. To investigate observed SST changes in different basins, we use the Hadley Centre Sea Ice and Sea Surface Temperature dataset (HadISST, Rayner et al. 2003). The same dataset was also used to drive the atmospheric models.

In addition, as the African rainforest is mainly distributed in the equatorial Congo Basin and is characterized by seasonal wetting-drying cycles, we calculate the changes of precipitation over the rainforest $\left(7^{\circ} \mathrm{E}-32^{\circ} \mathrm{E}\right.$, $4^{\circ} \mathrm{S}-5^{\circ} \mathrm{N}$ ) in the boreal winter dry season (DJF) and boreal spring wet season (AM) from 1979 to 2015. The Sen's slope method (Sen 1968) are adopted to calculate observed and simulated trends, and their confidence intervals was estimated using a Mann-Kendall test (Richard 1987). These two methods are non-parametric and robust in the existence of outliers. For the following model simulations, we also use the same method to analyze.

To understand the mechanism of precipitation change, we examine the trend of Walker circulation and moisture by using Sen's slope. Walker circulation is based on zonal mass stream function, is given by $\mathrm{Yu}$ and Zwiers (2010) and $\mathrm{Yu}$ et al. (2012): $\Psi=\frac{a \Delta \varphi}{g} \int_{0}^{\mathrm{p}} u_{D} d p$, where $\Psi$ is the zonal mass stream function, $a$ is the Earth radius, $\Delta \varphi$ is the width of the $5^{\circ} \mathrm{S}-5^{\circ} \mathrm{N}$ band along the equator in radians, $g$ is the gravitational acceleration, $u_{D}$ is the divergent 
component of the zonal wind, and $\mathrm{p}$ is the pressure. In addition to analyzing the moisture and wind at $825 \mathrm{hPa}$, we also calculate the divergence of vertically integrated moisture flux (Satyamurty et al. 2013), defined as $D_{w}=\nabla \cdot F_{w}, F_{w}=\int q \mathrm{Vdp} / g . \mathbf{F}_{\mathrm{W}}$ is vertically integrated moisture flux. $\mathrm{q}$ is specific humidity, $\mathrm{V}$ is vector wind, and $\mathrm{p}$ is pressure. The moisture fluxes are integrated from the surface to $300 \mathrm{hPa}$ because water vapor content above $300 \mathrm{hPa}$ is negligible. One of the focuses of this study is how the SST change in tropical basin in the recent decades influences African rainforest precipitation. However, different basins interact with each other on interannual and decadal timescales. Results in atmospheric models do not reflect inter-basin interaction, and are thus typically used to isolate the role of different basins. As a result, the NCAR atmospheric model, Community Atmosphere Model version 4 (CAM4, Neale et al. 2013) is used to investigate the atmospheric responses to the observed SST trend in different ocean basins. The finite volume dynamical core is used in CAM4 models with F19 horizontal resolution $\left(\sim 2^{\circ}\right)$. We designed three SST forcing experiments by the tropical Atlantic, Indian and Pacific Ocean, respectively. Given the importance of the inter-basin interactions, we also designed the experiment forced by the observed SST variability over the tropical ocean. The model is forced by observed SST variability from 1979 to 2015 in the target basin, while the model is driven by climatological SST in the other basins. The configuration of each target basin is the tropical ocean region from $20^{\circ} \mathrm{S}$ to $20^{\circ} \mathrm{N}$, i.e., Atlantic Ocean between $20^{\circ} \mathrm{S}$ and $20^{\circ} \mathrm{N}$, Pacific Ocean between $20^{\circ} \mathrm{S}$ and $20^{\circ} \mathrm{N}$, and Indian Ocean between $20^{\circ} \mathrm{S}$ and $20^{\circ} \mathrm{N}$. Buffer regions are $30^{\circ} \mathrm{S}-20^{\circ} \mathrm{S}$ and $20^{\circ} \mathrm{N}-30^{\circ} \mathrm{N}$ in each experiment. Strength of SST forcing over buffer regions is gradually reduced. In addition, the SSTs outside of the tropical region are fixed to the climatological value. There is no coupling outside of the tropical region in the model. We conducted 12-member ensemble simulations in the experiments for each ocean basin. The 12-member ensemble simulations are generated by slightly different observed SST trend in each target basin. By examining the change of the ensemble-mean, we could understand the contribution to precipitation change by the individual ocean basin.

\section{Results}

\section{Observed changes in African rainforest precipitation}

Given regional distribution of African rainforest, we focus on the domain marked by black box in Fig. 1a $\left(7^{\circ} \mathrm{E}-32^{\circ} \mathrm{E}, 4^{\circ} \mathrm{S}-5^{\circ} \mathrm{N}\right)$. We further calculate the climatology of area-averaged precipitation in each month (Fig. 1b). As suggested in previous studies, a typically bimodal seasonal precipitation feature is apparent in this region.
The boreal winter (DJF) is a clear dry season, with climatological precipitation of $3.15-3.31 \mathrm{~mm} /$ day. In the next few months, climatological precipitation starts to exceed $5 \mathrm{~mm} /$ day, which means wet season is coming. In particular, in April and May, the rainforest receives the highest precipitation in the first half of the year. In addition, Jiang et al (2019) had revealed that the earlier dry season (JJA) onset was related to the change of precipitation during the AMJ over the Congo basin. Accordingly, we only choose the boreal winter dry season (DJF) and boreal spring wet season (AM) to examine the seasonality of precipitation over the African rainforest regions in past decades. Without special explanation, the boreal winter dry season is DJF and the boreal spring wet season is $\mathrm{AM}$ in later sections.

Figure 2 shows the observed precipitation trend in the boreal winter dry season (Fig. 2a, b) and boreal spring wet season (Fig. 2c, d) from 1979 to 2015. Remarkably, two observational datasets show similar spatial patterns, with a significant increasing (deep green color) trend in DJF and a decreasing trend (deep brown color) in AM. In the dry season, the largest positive precipitation trends are mainly distributed in the west and east of the domain (Fig. 2a, b). However, in the wet season, stronger negative precipitation trends are not confined to the eastern rainforest, but widely extended to East African Plateau (Fig. 2c, d). Observations exhibit an opposite sign of trend in two seasons, whereas the drought in the boreal spring appears to be more extensive. We also analyzed the precipitation trends from 1979 to 2019 (Additional file 1: Fig. S1). The trends in observations over African rainforest do not change much when extended to 2019.

Observed patterns indicate different amounts of precipitation change during the boreal winter dry season and boreal spring wet season (Fig. 2). Therefore, we show the quantitative features of precipitation in Fig. 3. The results of GPCP and CMAP are nearly identical. Time series of precipitation show an increasing in DJF (Fig. 3a) and a decreasing in AM (Fig. 3b) since 1979. Spatially averaged precipitation trends over the rainforest region (Fig. 3c) suggest that the observed precipitation anomalies are statistically significant at the $5 \%$ level, with magnitudes of $\sim 0.13 \mathrm{~mm} /$ day/decade in DJF and $\sim 0.21 \mathrm{~mm} /$ day/decade in AM.

All observational datasets show a dramatic weakening of seasonality of precipitation over Africa rainforest region. Seasonal precipitation changes from 1979 to 2015 account for $14 \%$ of their respective climatological means $(\sim 3.23 \mathrm{~mm} /$ day in DJF and $\sim 5.65 \mathrm{~mm} /$ day in AM). To a large extent, the change of convective precipitation is modulated by tropical SST. In past decades, three tropical ocean basins experience different SST trends, namely a warming in the Atlantic, 


\section{Precipitation trend in observations}

\section{a DJF trend in GPCP}

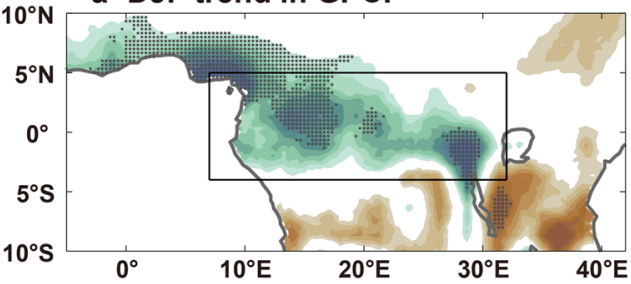

c AM trend in GPCP

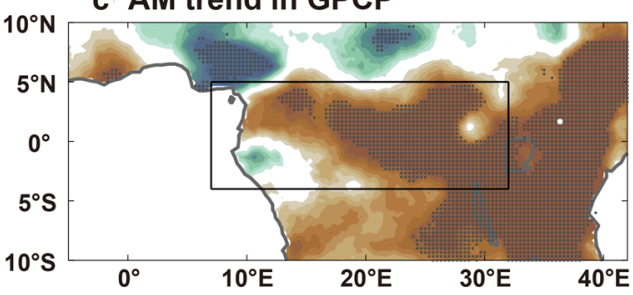

b DJF trend in CMAP

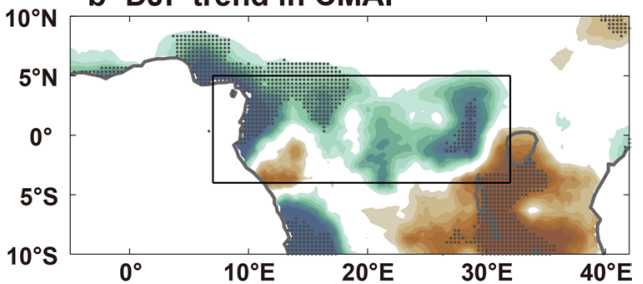

d AM trend in CMAP

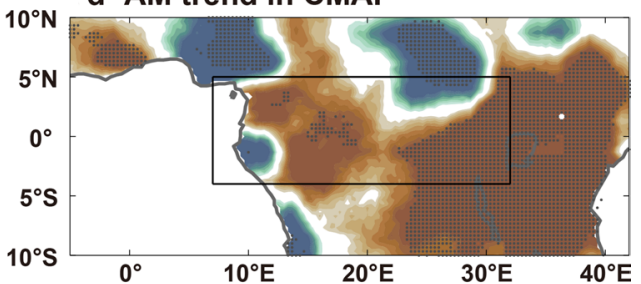

$\begin{array}{llllllllll}-0.25 & -0.2 & -0.15 & -0.1 & -0.05 & 0.05 & 0.1 & 0.15 & 0.2 & 0.25 \\ m m / d a y / d e c a d e\end{array}$

Fig. 2 Seasonal precipitation changes in observational datasets from 1979 to 2015. Color mapping represents the precipitation change (increase, dark green; decrease, dark brown). Dark dots indicate that precipitation trends are significant at the 5\% level. Upper panels (a, b) show the precipitation change during the boreal winter dry season (DJF) from GPCP and CMAP. Lower panels (c, $\mathbf{d})$ same as $\mathbf{a}, \mathbf{b}$ but for the boreal spring wet season (AM)
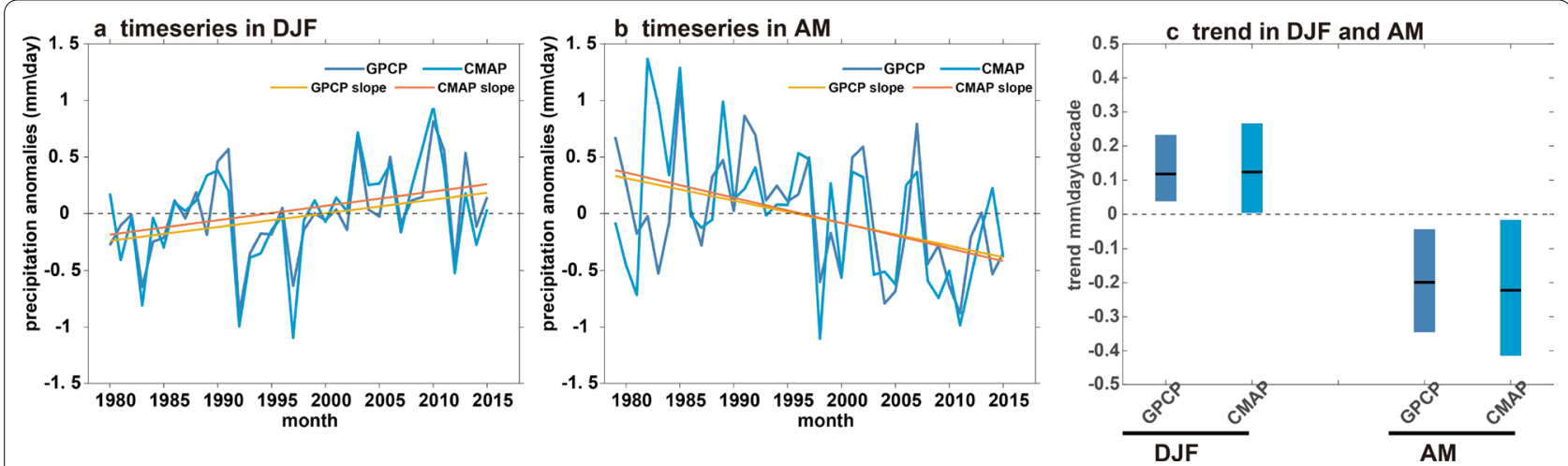

Fig. 3 The statistics of spatial averaged precipitation in observations. $\mathbf{a}, \mathbf{b}$ Time series of observed precipitation anomalies over the African rainforest (dark box in Fig. 2) show an intensified tendency during the boreal winter dry season and a weaken tendency during the boreal spring wet season. c The black lines and thick bars represent precipitation change and 95\% confidence intervals

Indian and western Pacific Ocean, and a cooling in central-eastern Pacific (Kosaka and Xie 2013; Li et al. 2016; McGregor et al. 2014). SST changes can be further attributed to the positive phase of the Atlantic Multidecadal Oscillation (AMO) and the cooling phase of the Pacific Decadal Oscillation (PDO; Kamae et al. 2017). These SST trends play key roles in changing regional or global climate. In particular, the warming of Atlantic and Indian Ocean may be more relevant to the change of precipitation in Africa. Therefore, we use atmospheric models to conduct experiments in order to quantify contribution of individual ocean basins to tropical African precipitation. 


\section{Impacts of tropical SST variabilities on the precipitation changes}

We first examine observed DJF and AM decadal SST trends (Fig. 4). As revealed in many studies, Atlantic and Indo-western Pacific show an apparent warming, but central-eastern Pacific shows an evident cooling. However, the amplitude of SST trends varies with season. The magnitude of warming in Atlantic and cooling in centralPacific in DJF is larger than that in AM, which may exert different effects in the corresponding season. Next, we add observed SST variability into the target basin to drive model and climatological SST in other ocean basins are used to drive model.

In order to test and to verify the simulation of atmospheric models, we compare the observed and simulated precipitation climatology (Fig. 5 and Additional file 1: Fig. S2). In the boreal winter dry season and boreal spring wet season, the climatological pattern is reasonably reproduced by models, such as spatial distribution and transition of dry and wet season, although models usually
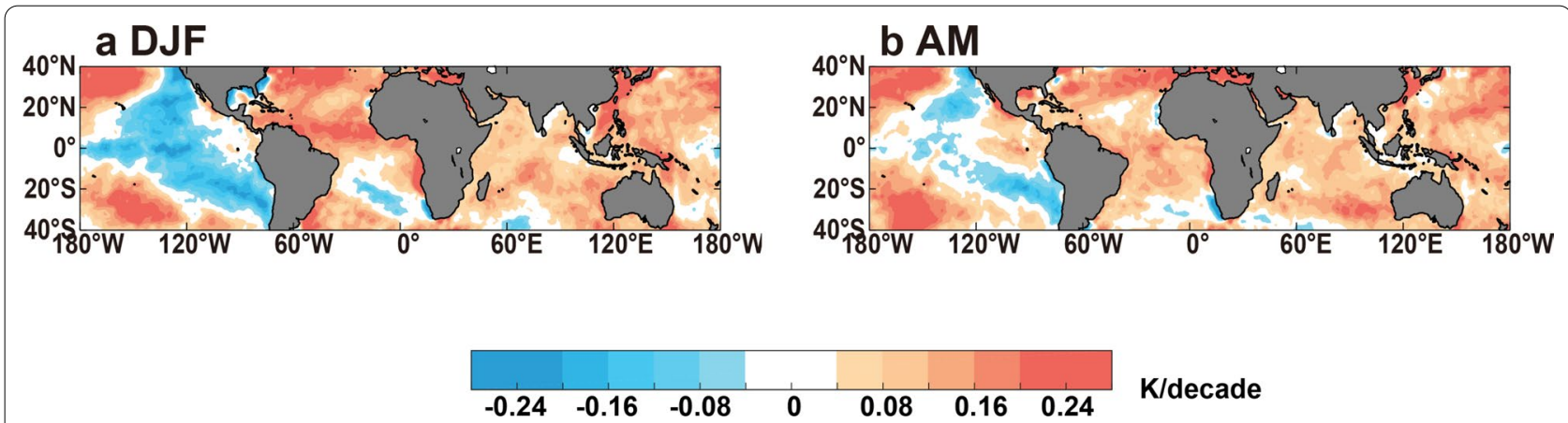

Fig. 4 Observed seasonal HadISST trend from 1979 to 2015. a, b Color mapping represents decadal SST change in DJF and AM

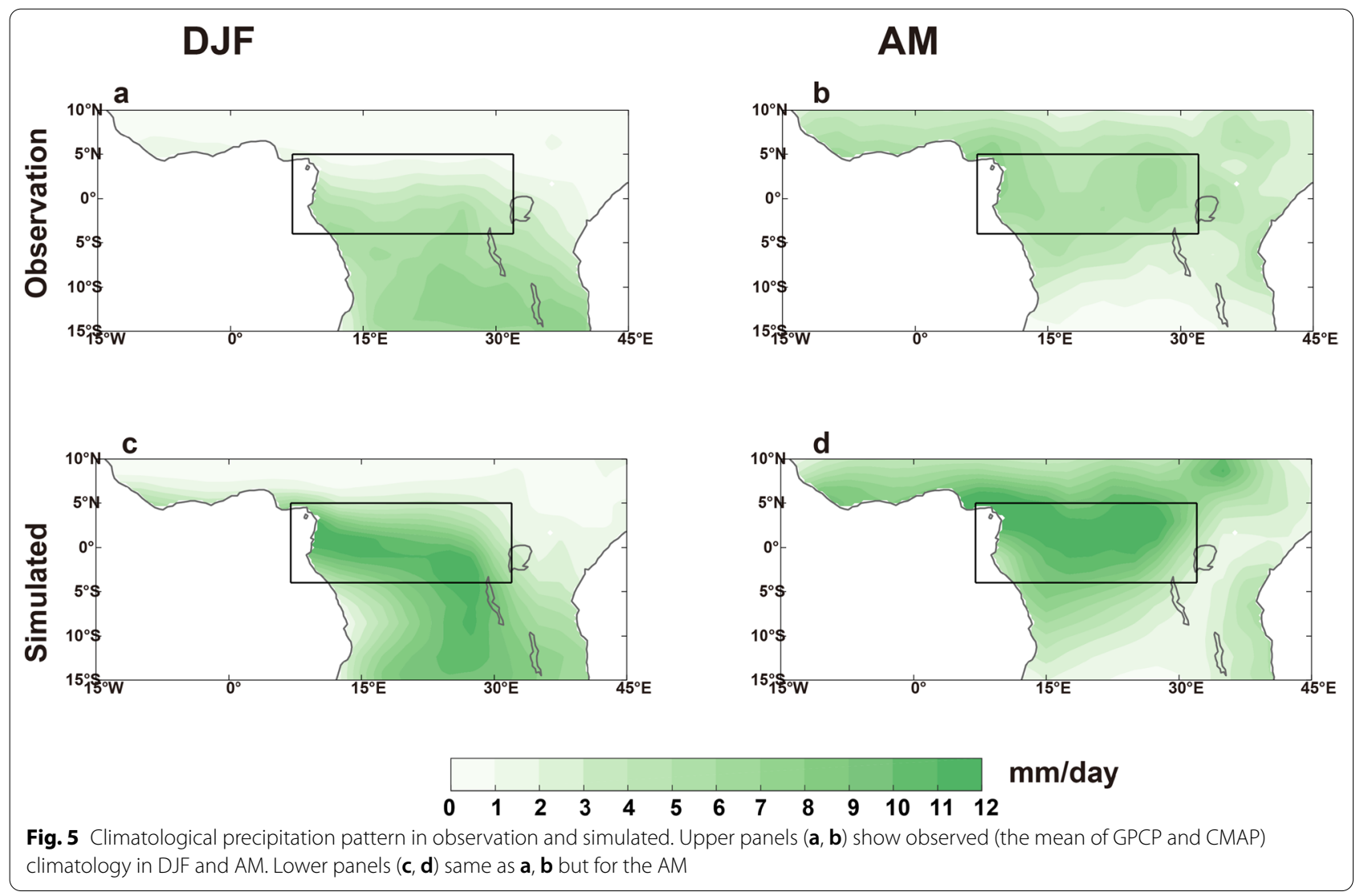


slightly overestimate precipitation. In addition, we examine the climatology of area-averaged precipitation in models from December to June (Additional file 1: Fig. S3). The seasonal cycle is reasonably reproduced, despite simulated heavy rainfalls in these months. We also calculated the standard deviation of precipitation (Additional file 1: Fig. S4). The variability over the domain in observations is smaller than that in models, especially in the boreal spring wet season. Further, we simulate the change of precipitation by running these models.

Forced by tropical SST, the precipitation changes in the domain are not well reproduced (Additional file 1: Fig. S5). However, simulated area-averaged precipitation trends are mainly characterized by wet (increased $\sim 0.02 \mathrm{~mm} /$ day/decade) during the boreal winter dry season and drought (decreased $\sim 0.13 \mathrm{~mm} /$ day/ decade) during the boreal spring wet season from 1979 to 2015. Figure 6 displays the precipitation trends by forcing three ocean basins: the tropical Atlantic, Indian and Pacific, respectively. During the boreal winter dry season, the model responses to the tropical Atlantic show the closest resemblance to the observation (Fig. 6a, the pattern correlation of precipitation change in Additional file 1: Table. S1), while the responses to tropical Indian and Pacific Ocean are opposite to those in observations (Fig. 6b-c). Regional difference is obvious although the model (forced by Atlantic SST) simulate the enhanced precipitation trend. Observation increased precipitation mainly appears in the North of domain. However, the model responses to the Atlantic forcing display the strong positive trend in most of southern region. Overall, forced by tropical Atlantic Forcing, the model reproduces the strengthening pattern in central and western rainforest (Fig. 6a), implying that the Atlantic plays a leading role in the wetting in DJF while Indian and Pacific Ocean have completely opposite effect.

During the boreal spring wet season, significant negative anomalies appear over the African rainforest in three ocean forcing experiments. There was a certain degree of difference in the precipitation trend distribution between observations and modes (Fig. 6d-f). Reproduced decreased trends are mainly located in northwestern rainforest, albeit with enhanced trends in the southwest part. However, the amount and scope of drought are simulated by Indian and Pacific Ocean seem to be larger (Fig. 6e-f). Compared with observed trend in AM, the model responses to Indian Ocean forcing show the smallest magnitudes of increased precipitation over the southwest region (Fig. 6e) and model responses to Pacific forcing show the drying trend over the southeast region (Fig. 6f). These results indicate that Indian and Pacific Ocean have more important impacts on the drying in the AM.

The simulations in atmospheric models emphasize that the individual ocean basin has different impacts on African rainforest rainfall in the boreal winter dry season and boreal spring wet season. The enhanced precipitation in DJF is mainly attributed to the warming Atlantic forcing,

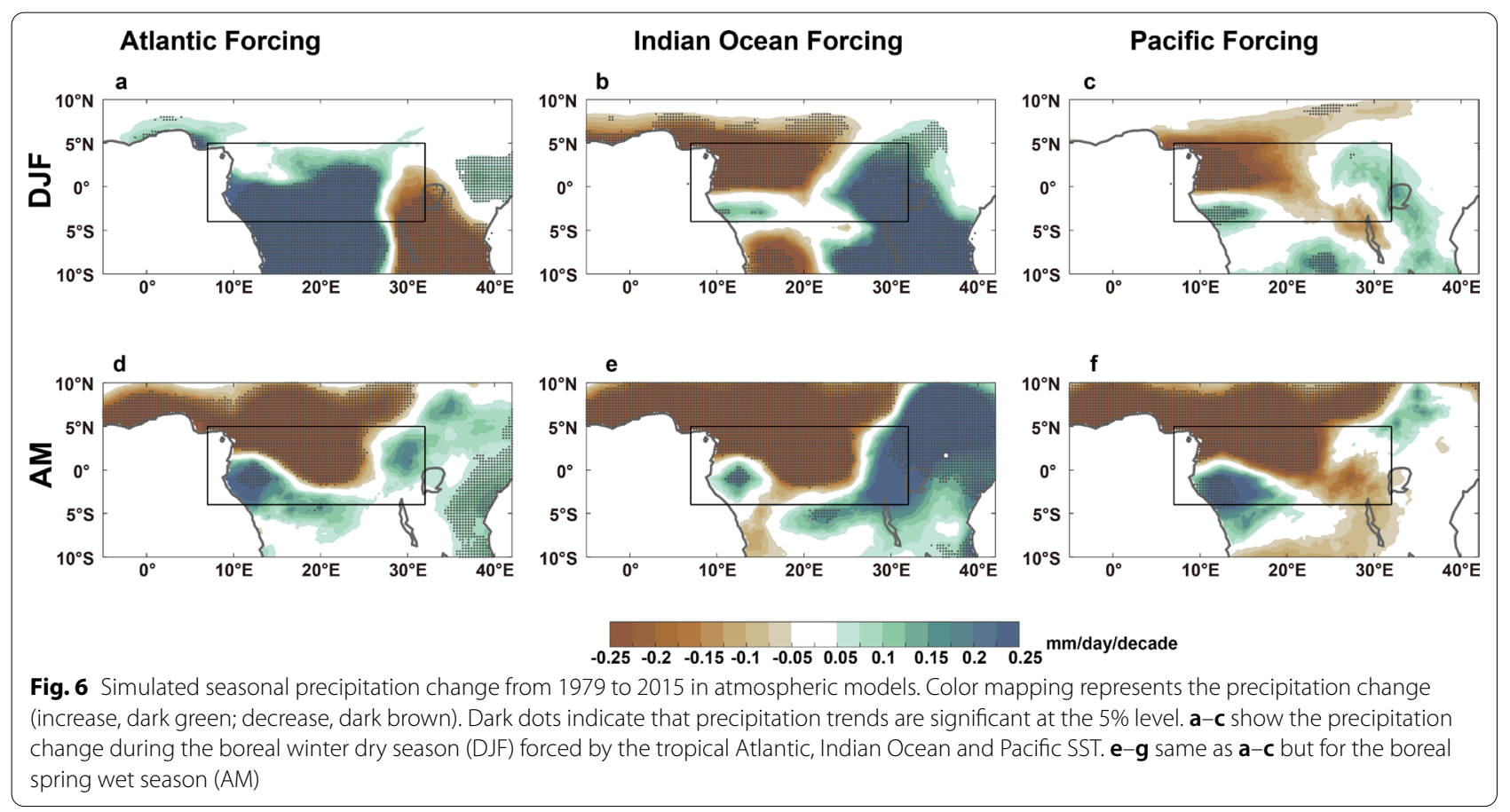


whereas the Indian and Pacific Oceans produce an opposite effect. The weakening precipitation in AM is driven by all three oceans, with Indian and Pacific Ocean making more contributions. Our numerical experiments show that individual SST forcing has important contributions in driving the change of precipitations over the equatorial African rainforest despite some differences in the simulated and observed trend. Especially in the boreal winter dry season, Atlantic SST forcing captures the increased precipitation trend, whereas Indian and Pacific SST forcing produces the opposite. As a result, the total simulated trend is not very similar to the observed. Interbasin interactions may play important roles in causing the differences. Three basins are tightly connected and interacted by atmospheric bridges. Indian and Pacific SST could potentially affect the precipitation by inter-basin interactions. The linear effect of individual tropical oceans is relatively simple, whereas the combining effect of three ocean basin is extremely complex. Some nonlinear effects in model simulation are not very well established. In this study, we explore the roles of individual SST in driving equatorial African precipitation from a linear framework.
Some nonlinear effects including inter-basin interaction are needed to be investigated.

\section{Mechanisms of the precipitation changes}

Because African precipitation can be affected by the strength of the Walker circulation (Cook and Vizy 2016; Hua et al. 2016), we examine changes of the latter to clarify the processes that link precipitation over the African rainforest and tropical SST. Figure 7 shows the zonal mass stream function (Walker circulation) trend (shading) and climatology (contour) over the equatorial Africa in atmospheric models. And the divergent component of the zonal wind in stream function is averaged between $5^{\circ} \mathrm{S}$ and $5^{\circ} \mathrm{N}$. During the boreal winter dry season (DJF), significant positive trends appear in the core region of climatology simulated by Atlantic forcing (Fig. 7a), whereas negative trends appear under Indian Ocean forcing (Fig. 7b). Enhanced circulation associated with deep convection is closely linked to higher rainfall in DJF. During the AM, only Indian Ocean generates significant negative trends (Fig. 7e), with weakening circulation and less precipitation. Pacific forcing has no clear sign in either

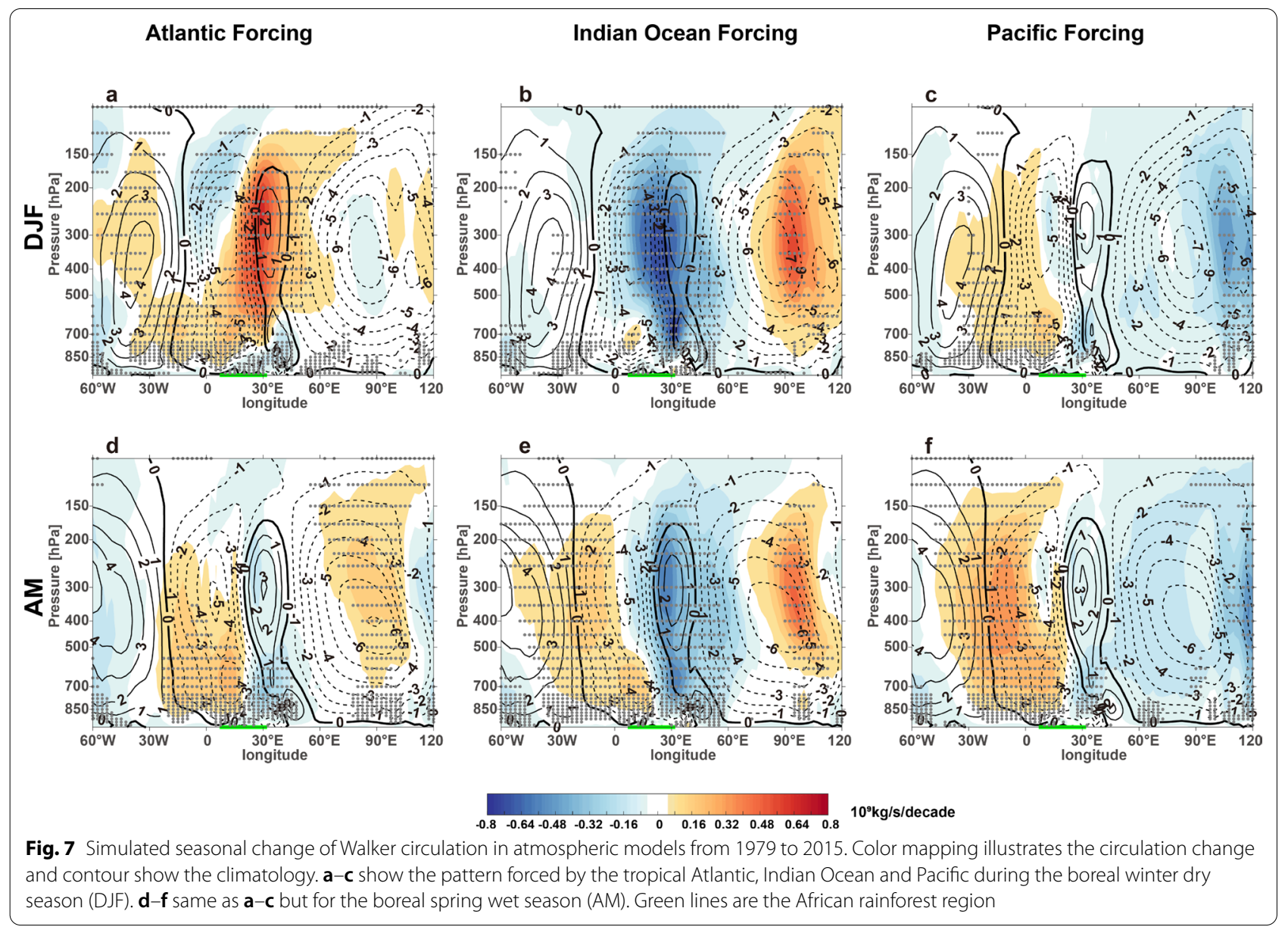


season (Fig. 7c, f). The strengthening (weakening) circulation is coherent with increased (decreased) precipitation in simulations.

SST is important driver for the changes of atmospheric circulation. In addition, SST forcing in different tropical basins also modulate the changes of precipitation by affecting the process of moisture. Changes of specific humidity and moisture flux convergence reflect evolutions in moisture, energy and convection in the air, which are intimately connected with precipitation (Chadwick et al. 2016; Gaffen and Ross 1999; Trenberth et al. 2011). Figure 8 shows the simulated anomaly specific humidity (moisture; color) and moisture flux (arrows) at $825 \mathrm{hPa}$. During the boreal winter dry season, strengthening moisture anomalies accompanied by typical convergence over the equatorial western African are driven by the tropical Atlantic forcing (Fig. 8a). However, forced by Indian and Pacific Ocean, simulations show the weakening moisture trend over the central and western part of the domain (Fig. 8b-c). Meanwhile, anomaly moisture flux show the divergence over the equatorial western Africa (Fig. 8b-c). The comparison of model responses suggests that warming Atlantic increases moisture and further leads to wetting trend in DJF (Fig. 6a). During the boreal spring wet season, the model responses all show decreased moisture and enhanced divergence (Fig. 8d-f), in particular forced by Indian and Pacific Ocean, causing corresponding dry trend in AM (Fig. 6d-f).

Simulated changes of vertically integrated moisture flux convergence (Fig. 9) resemble the changes of moisture at $825 \mathrm{hPa}$ (Fig. 8). There are significantly negative correlations between them in different SST forcing (pattern correlations in Additional file 1: Table.S2). Enhanced (reduced) moisture at low level is accompanied by strong convergence (divergence). In the boreal winter dry season, the tropical Atlantic forcing leads to a stronger moisture convergence, implying that more moisture is transported to the equatorial western Africa (Fig. 9a). Indian Ocean forcing induces the divergence (Fig. 9b) and Pacific forcing has no obvious signs (Fig. 9c). In the boreal spring wet season, the simulation results are consistent regarding more divergence (Fig. 9d-f), with a more widespread area driven by Indian Ocean forcing, which have a substantial impact on decreasing precipitation.

Overall, recent SST pattern causes changes of the Walker circulation and thus the moisture flux over the equatorial Africa, which increases precipitation in the boreal winter dry season and decreases precipitation in the boreal spring wet season. The variation of Atlantic and Indian Ocean forcing with season are more evident. Warming Atlantic drivers intensified Walker circulation

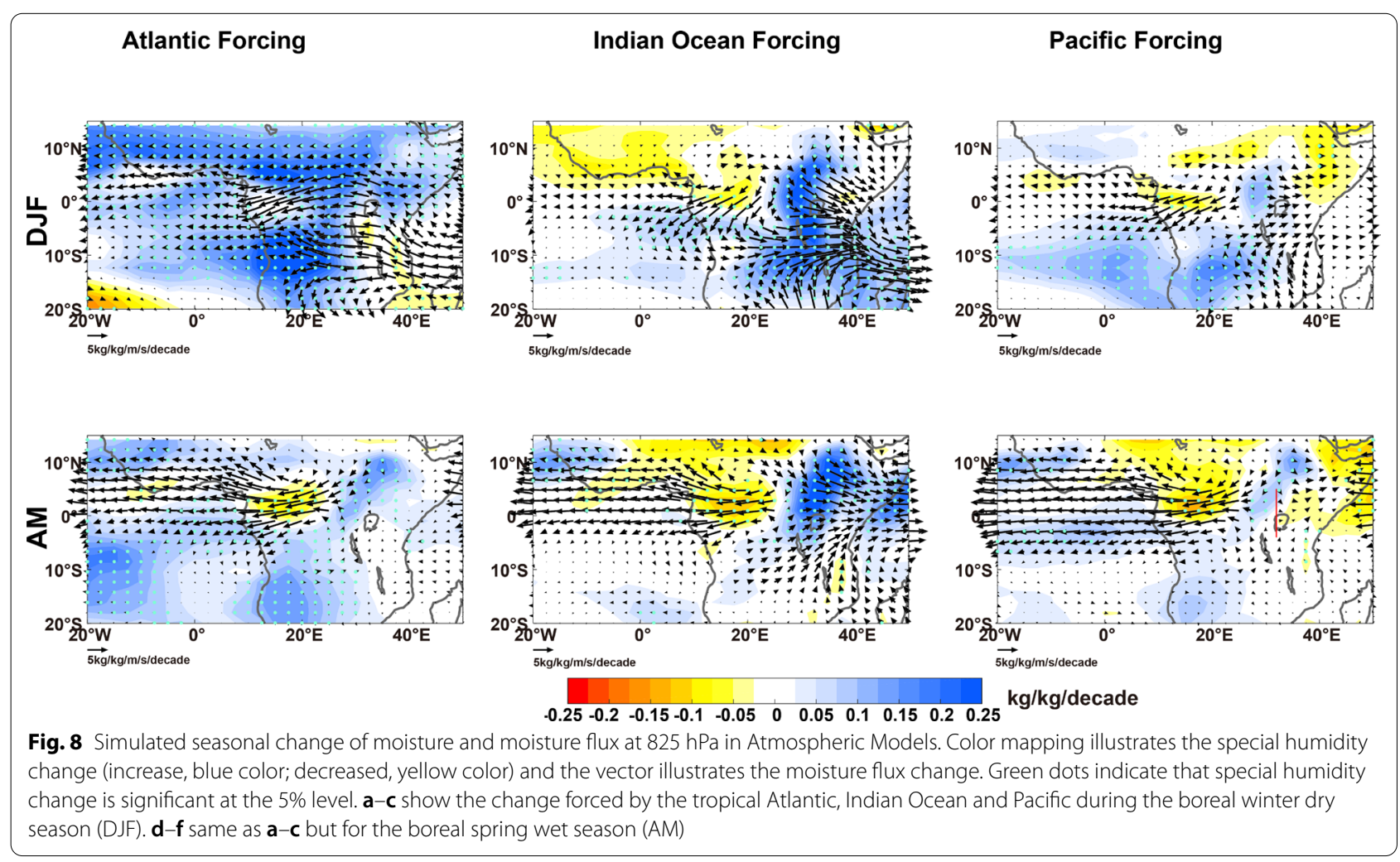




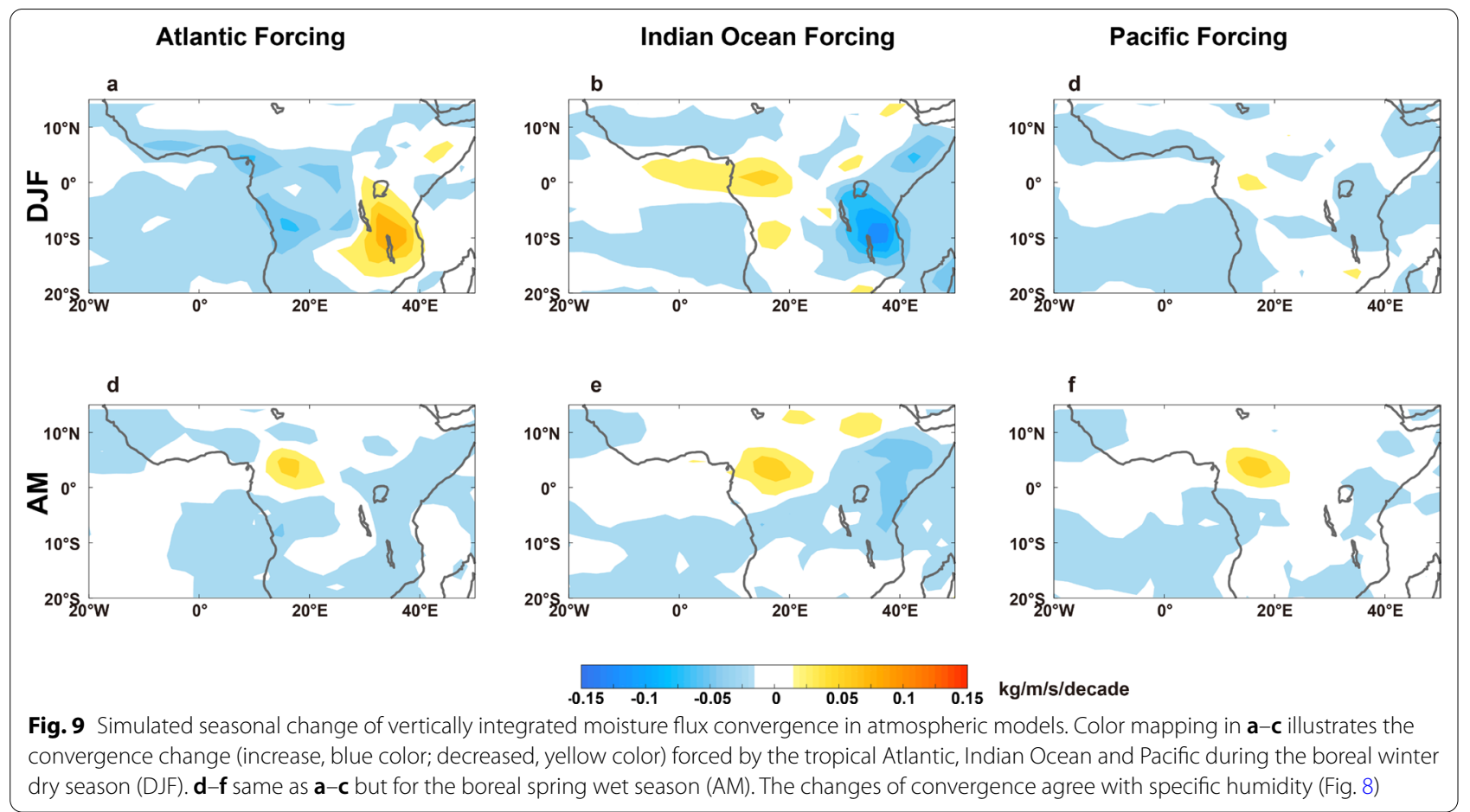

over the Africa and thus lead to the increase of moisture convergence associated with deep convection and further strengthens precipitation in the boreal winter dry season. However, warming Indian Ocean weakens Walker circulation and the corresponding convergences in the boreal spring wet season, causing reductions in precipitation.

\section{Conclusions and discussion}

In this study, we examine the changes of precipitation over the African rainforest during the boreal winter dry season and boreal spring wet season from 1979 to 2015 by using observational precipitation datasets. We reveal that the seasonality of precipitation is dramatically weakened in observations, i.e., the wetting trend in the boreal winter dry seasons and the drying trend in the boreal spring wet season. The increased precipitation anomaly is $\sim 0.13 \mathrm{~mm} /$ day/decade in DJF and decreased anomaly is $\sim 0.21 \mathrm{~mm} /$ day/decade from 1979 to 2015 in $\mathrm{AM}$, accounting for $14 \%$ (the precipitation changes from 1979 to 2015) of the climatology. As revealed in atmospheric models (CAM4), these changes are driven by tropical seasonal SST forcing, in particular the Atlantic and the Indian Ocean. Simulations show that the warming of the tropical Atlantic plays a key role in intensifying zonal circulation and moisture convergence over the equatorial Africa in boreal winter dry season, resulting in positive precipitation anomalies. However, warming Indian Ocean makes more contribution to weakening circulation and convection, leading to negative precipitation anomalies in boreal spring wet season.

However, the mechanism of seasonal precipitation change is mainly based on numerical simulations of a state-of-the-art atmospheric model. The relationship between SST and precipitation is extraordinarily complex in real world. In our study, observed intensified precipitation in the boreal winter dry season is only partly explained by Atlantic forcing. The model responses to Indian and Pacific Ocean forcing show negative precipitation anomalies in this dry season. Warming Atlantic plays an important role in strengthening moisture flux and warming Indian Ocean suppresses the convergence in DJF. The whole process tends to be nonlinear, and therefore the specific relationship between different SST and precipitation needs further study. In addition, for the other dry season (JJA) and wet season (SON), it is worthwhile to investigate whether the seasonality of precipitation weakens or strengthens and the roles of SST in the future.

The precipitation is of great importance to African rainforest and even the entire tropics. In recent decades, observed precipitation increased during the boreal winter dry season and decreased during the boreal spring wet season over the African rainforest. The opposite change of precipitation could cause a wetter dry season and a drier wet season, which may dramatically impact on the hydrological and ecosystem over the entire continent and 
around. Meanwhile, the deep convection associated with precipitation in different seasons, may have a further effect on the global circulation and potentially impact on the global climate system.

\section{Supplementary Information}

The online version contains supplementary material available at https://doi. org/10.1186/s40562-021-00192-w.

Additional file 1: Figure S1. Same as Fig. 2, but for the precipitation trends from 1979 to 2019. Upper Panels (a, b) show the precipitation change during the boreal winter dry season (DJF) from GPCP and CMAP. Lower Panels $(c, d)$ same as $(a, b)$ but for the boreal spring wet season (AM). Figure S2. Same as Fig. 5, but for the climatological precipitation pattern in GPCP and CMAP. Upper Panels (a, b) show observed climatology in GPCP. Lower Panels (c, d) same as (a, b) but for CMAP. Figure S3. same as Fig. $1 \mathrm{~b}$, but for spatial averaged (the box in Fig. $1 \mathrm{a}, 7^{\circ} \mathrm{E}-32^{\circ} \mathrm{E}, 4^{\circ} \mathrm{S}-$ $5^{\circ} \mathrm{N}$ ) climatology of monthly precipitation in CAM model. Figure S4. The standard deviation of seasonal precipitation pattern in GPCP and CMAP. Left Panel $(a, d)$ show the results in GPCP. Middle Panels $(b, e)$ same as $(a, d)$ but for CMAP. Right Panels (c, f) same as (a, d) but for models. Figure S5. Same as Fig. 6, but forced by tropical Ocean SST in atmospheric models. $\mathrm{a}$ is precipitation in DJF and b is precipitation in AM. Table S1. Pattern correlations of precipitation trends between observations and models. The region is $7^{\circ} \mathrm{E}-32^{\circ} \mathrm{E}, 4^{\circ} \mathrm{S}-5^{\circ} \mathrm{N}$. Table S2. Pattern correlations between the trend of moisture at $825 \mathrm{hPa}$ and the trend of divergence of vertically integrated moisture flux. The region is $7^{\circ} \mathrm{E}-32^{\circ} \mathrm{E}, 4^{\circ} \mathrm{S}-5^{\circ} \mathrm{N}$.

\section{Acknowledgements}

This work was supported by the National Key Research and Development Program of China (Grant No. 2016YFA0601802), the Key Research Program of Frontier Sciences, CAS (Grant No. ZDBS-LY-DQC010) and the National Natural Science Foundation of China (Grant No. 41676190 and No. 41976193).

\section{Authors' contributions}

XL performed the model experiments. X-YW analyzed the datasets and wrote the manuscript. All authors contributed to the manuscript revision. All authors read and approved the final manuscript.

\section{Funding}

This work was funded by the National Key Research and Development Program of China (Grant No. 2016YFA0601802), the Key Research Program of Frontier Sciences, CAS (Grant No. ZDBS-LY-DQC010) and the National Natural Science Foundation of China (Grant No. 41676190 and No. 41976193).

\section{Availability of data and materials}

MODIS land cover map dataset (MCD12C1) is available at https://pdaac.usgs. gov/get_data. Observational precipitation (GPCP and CMAP) is download from The NOAA Earth System Research Laboratory's Physical Sciences Division (https://www.esrl.noaa.gov/psd/data/gridded/tables/precipitation.html). Model datasets and materials analyzed in this study are accessible from the corresponding author under reasonable request.

\section{Declarations}

\section{Competing interests}

The authors declare that they have no competing interests.

\section{Author details}

${ }^{1}$ Institute of Atmospheric Physics, Chinese Academy of Sciences, Beijing, China. ${ }^{2}$ University of Chinese Academy of Sciences, Beijing, China. ${ }^{3}$ State Key Laboratory of Satellite Ocean Environment Dynamics, Second Institute of Oceanography, Ministry of Natural Resources, Hangzhou, China.

Received: 18 September 2020 Accepted: 17 May 2021 Published online: 07 June 2021

\section{References}

Asefi-Najafabady S, Saatchi S (2013) Response of African humid tropical forests to recent rainfall anomalies. Phil Trans R Soc B 368(1625):20120306

Baccini A, Goetz S, Walker W, Laporte N, Sun M, Sulla-Menashe D, Hackler J, Beck P, Dubayah R, Friedl M (2012) Estimated carbon dioxide emissions from tropical deforestation improved by carbon-density maps. Nat Clim Chang 2(3):182-185

Balas N, Nicholson S, Klotter D (2007) The relationship of rainfall variability in West Central Africa to sea-surface temperature fluctuations. Int J Climatol 27(10):1335-1349

Camberlin P, Janicot S, Poccard I (2001) Seasonality and atmospheric dynamics of the teleconnection between African rainfall and tropical sea-surface temperature: Atlantic vs ENSO. Int J Climatol 21 (8):973-1005

Chadwick R, Good P, Willett K (2016) A simple moisture advection model of specific humidity change over land in response to SST warming. I Clim 29(21):7613-7632

Chambers JQ, Roberts DA (2014) Drought in the Congo Basin. Nature 509(7498):36-38

Cook KH, Vizy EK (2016) The Congo Basin Walker circulation: dynamics and connections to precipitation. Clim Dyn 47(3-4):697-717

Creese A, Washington R (2018) A process-based assessment of CMIP5 rainfall in the Congo Basin: the September-November rainy season. J Clim 31(18):7417-7439

Dezfuli AK, Zaitchik BF, Gnanadesikan A (2015) Regional atmospheric circulation and rainfall variability in south equatorial Africa. J Clim 28(2):809-818

Diem JE, Ryan SJ, Hartter J, Palace MW (2014) Satellite-based rainfall data reveal a recent drying trend in central equatorial Africa. Clim Change 126(1-2):263-272

DiNezio PN, Vecchi GA, Clement AC (2013) Detectability of changes in the walker circulation in response to global warming. J Clim 26(12):4038-4048

Farnsworth A, White E, Williams CJ, Black E, Kniveton DR (2011) Understanding the large scale driving mechanisms of rainfall variability over Central Africa. In: Williams CJR, Kniveton DR (eds) African climate and climate change. Springer, Dordrecht, pp 101-122

Friedl MA, Sulla-Menashe D, Tan B, Schneider A, Ramankutty N, Sibley A, Huang X (2010) MODIS Collection 5 global land cover: Algorithm refinements and characterization of new datasets. Remote Sens Environ 114(1):168-182

Gaffen DJ, Ross RJ (1999) Climatology and trends of US surface humidity and temperature. J Clim 12(3):811-828

Ha K-J, Kim B-H, Chung E-S, Chan JCL, Chang C-P (2020) Major factors of global and regional monsoon rainfall changes: natural versus anthropogenic forcing. Environ Res Lett 15(3):034055

Hart NCG, Washington R, Maidment RI (2019) Deep convection over Africa: annual cycle, ENSO, and trends in the hotspots. J Clim 32(24):8791-8811

Hoerling M, Hurrell J, Eischeid J, Phillips A (2006) Detection and attribution of twentieth-century northern and southern African rainfall change. J Clim 19(16):3989-4008

Hua W, Zhou L, Chen H, Nicholson SE, Raghavendra A, Jiang Y (2016) Possible causes of the Central Equatorial African long-term drought. Environ Res Lett 11(12):124002

Huffman GJ, Adler RF, Bolvin DT, Gu G (2009) Improving the global precipitation record: GPCP Version 2.1. Geophys Res Lett. https://doi.org/10.1029/ 2009GL040000

Jackson B, Nicholson SE, Klotter D (2009) Mesoscale convective systems over western equatorial Africa and their relationship to large-scale circulation. Mon Weather Rev 137(4):1272-1294

James R, Washington R, Rowell DP (2013) Implications of global warming for the climate of African rainforests. Phil Trans R Soc B 368(1625):20120298

Jiang Y, Zhou L, Tucker CJ, Raghavendra A, Hua W, Liu YY, Joiner J (2019) Widespread increase of boreal summer dry season length over the Congo rainforest. Nat Clim Chang 9(8):617-622

Kamae Y, Li X, Xie S-P, Ueda H (2017) Atlantic effects on recent decadal trends in global monsoon. Clim Dyn 49(9-10):3443-3455

Kosaka Y, Xie S-P (2013) Recent global-warming hiatus tied to equatorial Pacific surface cooling. Nature 501 (7467):403-407

Leduc-Leballeur M, De Coëtlogon G, Eymard L (2013) Air-sea interaction in the Gulf of Guinea at intraseasonal time-scales: wind bursts and coastal precipitation in boreal spring. Q J R Meteorol Soc 139(671):387-400 
Li X, Xie S-P, Gille ST, Yoo C (2016) Atlantic-induced pan-tropical climate change over the past three decades. Nat Clim Chang 6(3):275-279

Lyon B, DeWitt DG (2012) A recent and abrupt decline in the East African long rains. Geophys Res Lett. https://doi.org/10.1029/2011GL050337

Maidment RI, Allan RP, Black E (2015) Recent observed and simulated changes in precipitation over Africa. Geophys Res Lett 42(19):8155-8164

Malhi Y, Wright J (2004) Spatial patterns and recent trends in the climate of tropical rainforest regions. Philos Trans R Soc Lond B Biol Sci 359(1443):311-329

Malhi Y, Adu-Bredu S, Asare RA, Lewis SL, Mayaux P (2013) African rainforests: past, present and future. Phil Trans R Soc B 368(1625):20120312

Mayaux P, Pekel J-F, Desclée B, Donnay F, Lupi A, Achard F, Clerici M, Bodart C, Brink A, Nasi R (2013) State and evolution of the African rainforests between 1990 and 2010. Phil Trans R Soc B 368(1625):20120300

McGregor S, Timmermann A, Stuecker MF, England MH, Merrifield M, Jin F-F, Chikamoto Y (2014) Recent Walker circulation strengthening and Pacific cooling amplified by Atlantic warming. Nat Clim Chang 4(10):888-892

Neale RB, Richter J, Park S, Lauritzen PH, Vavrus SJ, Rasch PJ, Zhang M (2013) The mean climate of the community atmosphere model (CAM4) in forced SST and fully coupled experiments. J Clim 26(14):5150-5168

Nicholson SE (2009) A revised picture of the structure of the "monsoon" and land ITCZ over West Africa. Clim Dyn 32(7-8):1155-1171

Nicholson SE (2018) The ITCZ and the seasonal cycle over equatorial Africa. Bull Am Meteor Soc 99(2):337-348

Nicholson SE, Dezfuli AK (2013) The relationship of rainfall variability in western equatorial Africa to the tropical oceans and atmospheric circulation. Part I: The boreal spring. J Clim 26(1):45-65

Otto FEL, Jones RG, Halladay K, Allen MR (2013) Attribution of changes in precipitation patterns in African rainforests. Phil Trans $\mathrm{R}$ Soc $B$ 368(1625):20120299

Pokam WM, Djiotang LAT, Mkankam FK (2012) Atmospheric water vapor transport and recycling in Equatorial Central Africa through NCEP/NCAR reanalysis data. Clim Dyn 38(9-10):1715-1729

Rayner N, Parker DE, Horton E, Folland CK, Alexander LV, Rowell D, Kent E, Kaplan A (2003) Global analyses of sea surface temperature, sea ice, and night marine air temperature since the late nineteenth century. J Geophys Res. https://doi.org/10.1029/2002JD002670

Redelsperger J-L, Thorncroft CD, Diedhiou A, Lebel T, Parker DJ, Polcher J (2006) African monsoon multidisciplinary analysis: an international research project and field campaign. Bull Am Meteor Soc 87(12):1739-1746

Richard GO (1987) Statistical methods for environmental pollution monitoring. Wiley

Richard Y, Fauchereau N, Poccard I, Rouault M, Trzaska S (2001) 20th century droughts in southern Africa: spatial and temporal variability, teleconnections with oceanic and atmospheric conditions. Int J Climatol 21(7):873-885

Saatchi SS, Harris NL, Brown S, Lefsky M, Mitchard ET, Salas W, Zutta BR, Buermann W, Lewis SL, Hagen S (2011) Benchmark map of forest carbon stocks in tropical regions across three continents. Proc Natl Acad Sci 108(24):9899-9904
Satyamurty P, Wanzeler da Costa CP, Manzi AO (2013) Moisture source for the Amazon Basin: a study of contrasting years. Theor Appl Climatol 111(1-2):195-209

Sen PK (1968) Estimates of the regression coefficient based on Kendall's tau. J Am Stat Assoc 63(324):1379-2000

Shanahan TM, Overpeck JT, Anchukaitis K, Beck JW, Cole JE, Dettman DL, Peck JA, Scholz CA, King JW (2009) Atlantic forcing of persistent drought in West Africa. Science 324(5925):377-380

Sultan B, Janicot S (2000) Abrupt shift of the ITCZ over West Africa and intraseasonal variability. Geophys Res Lett 27(20):3353-3356

Thorncroft CD, Nguyen H, Zhang C, Peyrillé P (2011) Annual cycle of the West African monsoon: regional circulations and associated water vapour transport. Q J R Meteorol Soc 137(654):129-147

Todd MC, Washington R (2004) Climate variability in central equatorial Africa: Influence from the Atlantic sector. Geophys Res Lett. https://doi.org/10. 1029/2004GL020975

Trenberth KE, Fasullo JT, Mackaro J (2011) Atmospheric moisture transports from ocean to land and global energy flows in reanalyses. J Clim 24(18):4907-4924

Washington R, James R, Pearce H, Pokam WM, Moufouma-Okia W (2013) Congo Basin rainfall climatology: can we believe the climate models? Phil Trans R Soc B 368(1625):20120296

Webster PJ (1973) Temporal variation of low-latitude zonal circulations. Mon Weather Rev 101(11):803-816

Williams AP, Funk C (2011) A westward extension of the warm pool leads to a westward extension of the Walker circulation, drying eastern Africa. Clim Dyn 37(11-12):2417-2435

Xie PP, Arkin PA (1997) Global precipitation: A 17-year monthly analysis based on gauge observations, satellite estimates, and numerical model outputs. Bull Amer Meteor Soc 78(11):2539-2558

Yin X, Gruber A (2010) Validation of the abrupt change in GPCP precipitation in the Congo River Basin. Int J Climatol 30(1):110-119

Yin XG, Gruber A, Arkin P (2004) Comparison of the GPCP and CMAP merged gauge-satellite monthly precipitation products for the period 1979-2001. J Hydrometeorol 5(6):1207-1222

Yu B, Zwiers FW (2010) Changes in equatorial atmospheric zonal circulations in recent decades. Geophys Res Lett. https://doi.org/10.1029/2009GL0420

Yu B, Zwiers FW, Boer GJ, Ting MF (2012) Structure and variances of equatorial zonal circulation in a multimodel ensemble. Clim Dyn 39(9-10):2403-2419

Zhou L, Tian Y, Myneni RB, Ciais P, Saatchi S, Liu YY, Piao S, Chen H, Vermote EF, Song C (2014) Widespread decline of Congo rainforest greenness in the past decade. Nature 509(7498):86-90

\section{Publisher's Note}

Springer Nature remains neutral with regard to jurisdictional claims in published maps and institutional affiliations.

\section{Submit your manuscript to a SpringerOpen ${ }^{\circ}$ journal and benefit from:}

- Convenient online submission

- Rigorous peer review

- Open access: articles freely available online

- High visibility within the field

Retaining the copyright to your article

Submit your next manuscript at springeropen.com 